\title{
Natural Hazards \\ Geological risk assessment of Amtoudi Agadir in southern Morocco: a key case for sustainable cultural heritage \\ --Manuscript Draft--
}

\begin{tabular}{|c|c|}
\hline Manuscript Number: & \\
\hline Full Title: & $\begin{array}{l}\text { Geological risk assessment of Amtoudi Agadir in southern Morocco: a key case for } \\
\text { sustainable cultural heritage }\end{array}$ \\
\hline Article Type: & Manuscript \\
\hline Keywords: & Anti-Atlas Chain + Berber heritage + Risk factors + Local economy + Propositions \\
\hline Corresponding Author: & $\begin{array}{l}\text { Manuel Martín-Martín, Ph.D. } \\
\text { Alicante University } \\
\text { Alicante, Alicante SPAIN }\end{array}$ \\
\hline $\begin{array}{l}\text { Corresponding Author Secondary } \\
\text { Information: }\end{array}$ & \\
\hline Corresponding Author's Institution: & Alicante University \\
\hline $\begin{array}{l}\text { Corresponding Author's Secondary } \\
\text { Institution: }\end{array}$ & \\
\hline First Author: & Pedro Robles-Marín \\
\hline First Author Secondary Information: & \\
\hline Order of Authors: & Pedro Robles-Marín \\
\hline & Francesco Guerrera \\
\hline & Manuel Martín-Martín, Ph.D. \\
\hline & Giuliana Raffaelli \\
\hline & Francisco Javier Alcalá \\
\hline & Julian Tejera de León \\
\hline & Taj-Eddine Cherkaoui \\
\hline & Lahcen Asebriy \\
\hline & Iz-Eddine El Amrani \\
\hline & Santiago Moliner-Aznar \\
\hline Order of Authors Secondary Inform & \\
\hline Abstract: & $\begin{array}{l}\text { Medieval fortified granaries known as "agadirs" are very common in southern Morocco, } \\
\text { being catalogued as world cultural heritage by UN. These Berber buildings (made of } \\
\text { stones and tree trunks) usually located on rocky promontories, constitute historical } \\
\text { testimonials related to the origin of Morocco and, as tourist attractions, have a positive } \\
\text { impact on the local economy. The sustainability of these ancient monuments requires } \\
\text { geological-risk evaluations of the massif stability under the agadir with the proposal of } \\
\text { stabilization measures, and an architectonic analysis with appropriate maintenance of } \\
\text { the structural elements. An interdisciplinary study including climate, seismicity, } \\
\text { hydrology, geology, geomorphology, geotechnical surveys of the massif and diagnosis } \\
\text { of the degradation of structural elements have been performed on the Amtoudi Agadir, } \\
\text { selected as a case study. The main findings from this study are that the prevalent rocks } \\
\text { used for construction (coming from the underlying substratum) are good-quality arkosic } \\
\text { sandstones; the SW cliffs under the agadir are unstable under water saturation; some } \\
\text { masonry walls are too thin and lack interlocking stones and mortar; and failures in the } \\
\text { beams (due to flexure, fracture, and exhaustion in the resistance due to insect attacks } \\
\text { or plant roots) are common. The basic risk assessment of ancient buildings of cultural } \\
\text { heritage and their geologic substratum are needed especially in undeveloped areas } \\
\text { with limited capacity to implement durable conservation policies. Therefore, }\end{array}$ \\
\hline
\end{tabular}




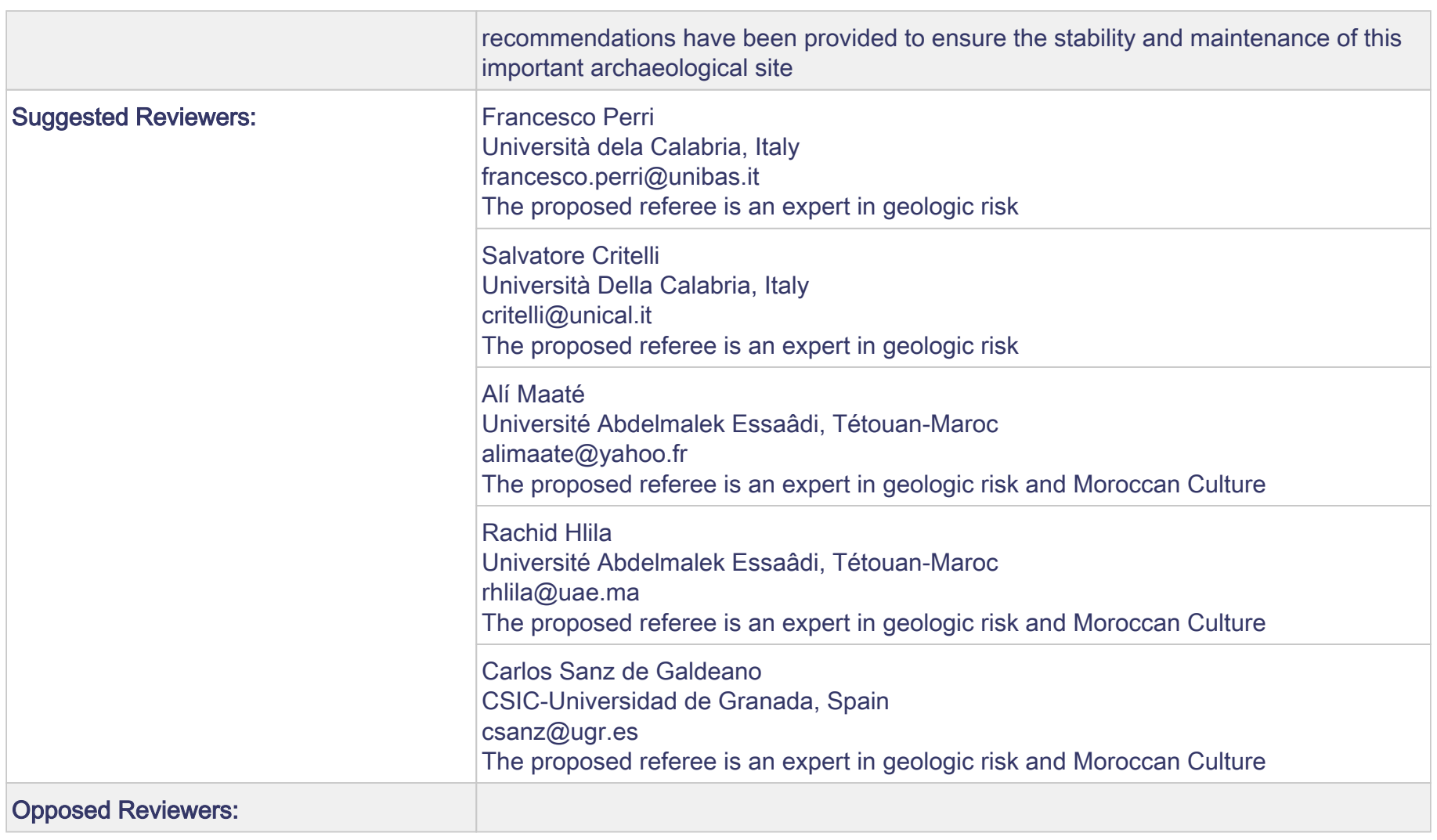




\title{
Geological risk assessment of Amtoudi Agadir in southern Morocco: a key case for sustainable cultural heritage
}

\author{
P. Robles-Marín ${ }^{1}$, F. Guerrera ${ }^{2}$, M. Martín-Martín ${ }^{3}$, G. Raffaelli ${ }^{2}$, F.J. Alcalá4 ${ }^{4}$ J. Tejera de León ${ }^{5}$, \\ T.E. Cherkaoui ${ }^{6}$, L. Asebriy ${ }^{5}$, I.E. El Amrani ${ }^{5}$ and S. Moliner-Aznar ${ }^{7}$ \\ ${ }^{1}$ Departamento de Ingeniería Civil, Alicante University, AP-99, E-03080, Spain \\ ${ }^{2}$ Dipartimento di Scienze della Terra, della Vita e dell'Ambiente (DiSTeVA), Università degli Studi di Urbino "Carlo Bo", \\ Campus Scientifico, 61029 Urbino, Italy \\ ${ }^{3}$ Departamento de Ciencias de la Tierra y Medio Ambiente, Alicante University, AP-99, E-03080, Alicante, Spain \\ ${ }^{4}$ Geo-Systems Centre (CVRM), Instituto Superiro Técnico, Universidade de Lisboa, 1049-001 Lisboa, Portugal \\ ${ }^{5}$ Département des Sciences de la Terre, Institut Scientifique, Université Mohammed V-Agdal, B.P.703, Rabat, Morocco \\ ${ }^{6}$ Department of Geophysics, Scientific Institute, Mohammed V University, B.P. \\ 703, 10106 Rabat (Morocco) - mt.cherkaoui@qmail.com \\ ${ }^{7}$ ESFERA, Consultores de Construcción S.L.P., 30007 Murcia, Spain
}

Corresponding author:

Manuel Martín-Martín

e-mail: manuel.martin.m3@gmail.com

tel: (+34) 965903400

\begin{abstract}
Medieval fortified granaries known as "agadirs" are very common in southern Morocco, being catalogued as world cultural heritage by UN. These Berber buildings (made of stones and tree trunks) usually located on rocky promontories, constitute historical testimonials related to the origin of Morocco and, as tourist attractions, have a positive impact on the local economy. The sustainability of these ancient monuments requires geological-risk evaluations of the massif stability under the agadir with the proposal of stabilization measures, and an architectonic analysis with appropriate maintenance of the structural elements. An interdisciplinary study including climate, seismicity, hydrology, geology, geomorphology, geotechnical surveys of the massif and diagnosis of the degradation of structural elements have been performed on the Amtoudi Agadir, selected as a case study. The main findings from this study are that the prevalent rocks used for construction (coming from the underlying substratum) are good-quality arkosic sandstones; the SW cliffs under the agadir are unstable under water saturation; some masonry walls are too thin and lack interlocking stones and mortar; and failures in the beams (due to flexure, fracture, and exhaustion in the resistance due to insect attacks or plant roots) are common. The basic risk assessment of ancient buildings of cultural heritage and their geologic substratum are needed especially in undeveloped areas with limited capacity to implement durable conservation policies. Therefore, recommendations have been provided to ensure the stability and maintenance of this important archaeological site.
\end{abstract}

Keywords Anti-Atlas Chain + Berber heritage + Risk factors + Local economy + Propositions 


\section{Introduction}

\subsection{Historical significance of the "agadirs"}

On the northern border of the Sahara Desert, the legacy of the millenary Berber culture has survived until today. The Berber tribes constructed "agadirs" to protect crops and livestock of the community, as well as themselves, from sudden attacks (Fig. 1). Therefore, agadirs, being a type of fortified citadel and granary dating from the $10^{\text {th }}$ century in some cases, were positioned on promontories close to inhabited areas with permanent water and food supplies, such as an oasis (Naji 2003). Agadirs were built with different architectural techniques and located directly on the bedrock, which supplied geo-materials for building, thus making the agadirs indistinguishable from the landscape when viewed from afar. Agadirs have played a key role throughout the history of the populations concerned, in the birth of their community identity and local laws. These constitute an important cultural heritage from the Berber people resulting in the origin of Morocco beginning from the northern migration of tribes from Mauritania. However, many agadirs are currently abandoned due to the modern lifestyle and the exodus of the rural population, while others persist due to the tourism attracted by historical legacy and desertic landscapes. This is the case of the Amtoudi Agadir, which is located in Wadi des Argan, a linear oasis.

Because the high importance of these cultural heritage buildings, as well as, to maintain the tourist pull on local economy, surveys for geological-risk assessment are needed to design a sustainable conservation policies.

\subsection{Geological-risk}

Due to their defensive character, agadirs were positioned in inaccessible sites such as rocky promontories with unstable vertical cliffs that posed potential geological risk. In addition, the ancestral construction techniques used do not substantially vary from the restoration ones still used by villagers. As a result, the underlying massif and the agadir show evidence of impending failure.

Studies on geological risk of historical sites include a complete geological evaluation of the area to deduce the influence of tectonic activity (volcanism, seismicity), gravitational processes (landsliding, screes, and fallen blocks), hallokinetic processes (collapses and bulging), hydrological processes (flooding and erosion), degradation, and conservation. The geological mapping together with the stratigraphic and geomorphologic characterization of the sites as well as an initial petrographic characterization of the rocks, are prerequisites. A seismic, volcanic, 
and hydrological characterization is necessary since these aspects act as catalysts or accelerators of further geo-hazards.

After these studies are performed, geotechnical surveys can be planned. These usually consist of: (1) geomechanic stations to characterize unconformities (stratification, jointing, faulting, foliation, and schistosity) through smith-hammer tests on the unconformity surfaces; (2) slope stability affecting the site; (3) laboratory tests on rocks for specific weight, bulk porosity, resistance, density, consistency, and angle of internal friction; and (4) analysis of slope stability by using data from the above-mentioned surveys and tests.

Initially, the architectural study of the agadir indicates the degree of conservation of the architectonic elements. On this basis, for both the geological site and the archaeological elements, certain corrective measures should be proposed to avoid deterioration and to define technical guides for conservation.

\subsection{Study performed}

This paper presents the overall geological-risk evaluation of the Amtoudi massif and agadir for a sustainable use. For this assessments were made of, the stability of the massif discontinuities and slopes of the Amtoudi area as well as the status of the building elements of the agadir: walls, pillars, ceilings structures, lintels and beams. Interdisciplinary surveys were conducted for: (1) the characterization of external forces for the massif stability (climate, geology, seismicity, and basin hydrology); (2) local surveys for massif stability, involving stratigraphy, geomorphology, and cliff geometry of the Amtoudi area including the agadir site, as well as petrography and geotechnical tests of the bedrock and the agadir's stones; and (3) diagnoses of the degree of conservation of the structural elements.

This paper is divided as follows: the Introduction is followed by characterizations of the main external forces for massif stability (climate and basin hydrology, geology framework and seismicity). The following section describes data acquisition for stratigraphy, petrography, geomorphology, and geotechnical of the massif (under the agadir) and the main structural constructive and architectonic elements of the agadir. The last two chapters discuss the risk assessment both of the massif and the agadir and present the main conclusions and proposals.

\section{Characteristics of the study area}

\subsection{Climate and basin hydrology}

The study area is located at the outlet of the "Wadi des Argan" hydrological basin $\left(9^{\circ} 01^{\prime}\right.$ $9^{\circ} 12^{\prime}$ W and $29^{\circ} 12^{\prime}-29^{\circ} 27^{\prime} \mathrm{N}$ ) in the province of Guelmim in southern Morocco (Fig. 2). The area has a subtropical dry climate with a bimodal precipitation distribution (Schulz 2008). Most of the 
precipitation $(\mathrm{P})$ occurs erratically during autumn and spring. Extreme rainfall events around 50 $\mathrm{mm}$ per day have been documented. In winter, cold northern winds predominate, while dry easterly winds occur in summer (Born et al. 2008). Annual mean $P$ is around $125 \mathrm{~mm}$ with a coefficient of variation of 0.45 over the period 1973-2011. Precipitation follows a decreasing gradient from West to East and from North to South controlled both by the entering south-western Atlantic weather cloud fronts as well as by elevation, respectively. Annual mean temperature is around $19.5^{\circ} \mathrm{C}$, with the minimum in January and maximum in August; the daily amplitude may be as high as $30^{\circ} \mathrm{C}$. Insolation is high, with more than 3500 hours per year in low-lying places. Annual mean potential evapotranspiration (EP) is around $1500 \mathrm{~mm}$. The mean daily EP:P ratio is around 0.2 , ranging from 0.1 in summer dry season to 0.3 in spring wet season; these values are indicative of arid climatic conditions (Arora 2002).

The Wadi des Argan basin, in the Amtoudi area, is sub-rounded with roughly a N-S axis, and covers a surface area $(A)$ of $286 \mathrm{~km}^{2}$, with a perimeter $(P)$ of some $88 \mathrm{~km}$. The basin has a main stream length $(L)$ of $43.5 \mathrm{~km}$, a main stream slope $(S)$ of 0.013 , and a mean elevation $\left(H_{M}\right)$ of $1230 \mathrm{~m}$ (outlet $\left(\mathrm{H}_{\mathrm{O}}\right)$ at $839 \mathrm{~m}$ to the south and a peak elevation at $1465 \mathrm{~m}$ to the north). Some common expressions were used to estimate the concentration time of the basin (Table 1), i.e. the time in which the flood peak arrives at the basin outlet after rainfall. This parameter enables a preliminary flood-risk evaluation in the area.

-Table 1

\subsection{Geological framework}

The study area belongs to the western Anti-Atlas Chain that characterizes the Atlas system in Morocco (Fig. 2A). The Anti-Atlas fold belt is located between the northern portion of the West African Craton (WAC), the High-Atlas Chain to the northern, and the Tindouf Basin to the south. The Anti-Atlas Chain is a part of the Appalachian-Ouachita-Mauritanides orogenic belt (Gasquet et al. 2008; and references therein) derived from the Appalachian orogeny and poorly affected by Alpine deformation. Normally it appears as a huge anticlinorium oriented SW-NE.

Schematically, the Anti-Atlas Chain is composed of two main different groups of formations: (1) a pre-Palaeozoic basement constituted by a set of metamorphic and sedimentary rocks and marked by a complex geologic and tectonic evolution (Ennih and Liégeois 2001; Burckard et al. 2006). This basement normally crops out as characteristic inliers and often in morphologically depressed areas; (2) an unconformable Palaeozoic sedimentary cover suite from the lowermiddle Cambrian dominated by shallow marine, mostly fine-grained, detritic deposits and carbonates deposited after an early Cambrian marine transgression. At the beginning of the Devonian, the sedimentation becomes carbonatic, indicating the end of the detritic supply coming from the Saharan bouclier. In the late Devonian, the tectonic regime changes (Hercynian orogeny) from the extensive (up to the Early Palaeozoic) to compressive that extends to the Permian. All these deposits normally make up the main relief of the study area 
because they are more resistant to erosion than are the pre-Cambrian crystalline basement rocks, which therefore crop out in the depressions.

The lower Palaeozoic stratigraphic record is documented, pointing out the presence of limestone rocks at the base of the transgression and thus mark the beginning of the new sedimentary cycle. After the carbonates, the sedimentation becomes detritic overall, forming arenitic and clayey formations with rich fauna, indicating low depth of the sedimentation corresponding to a stable marine platform. This platform extends into northern-western domain of the WAC where its large portions are progressively covered by transgressive deposits.

Structurally, the evolution of the Anti-Atlas Chain is controlled mainly by the Precambrian tectonic structures of the basement derived from Proterozoic poly-phase tectonics. Two major phases of deformation mark the Palaeozoic tectonic history of the Western Anti-Atlas (Soulaimani 1998) within the Hercynian orogenesis.

The unconformable Palaeozoic sedimentary cover on the pre-Cambrian basement is gently folded and shows a low degree of metamorphism without major detachments or thrust faults, making the Anti-Atlas a usual (intra-cratonic) type of belt that does not closely fit classic orogeny.

The main tectonic deformation of the Amtoudi area is characterized mainly by (a) folds affecting the entire sedimentary pile coverage from Adoudounien to the upper Devonian; and (b) normal slip faults trending generally between $\mathrm{N} 120^{\circ} \mathrm{E}, 80^{\circ} \mathrm{NNE}$ and $\mathrm{N} 145^{\circ} \mathrm{E}, 80^{\circ}$ vertical compatible compression NW-SE. In particular, the tectonic deformation of the sedimentary cover (Cambrian) is marked by folds trending NE-SW and sub-horizontal axes or slightly dipping to the SW or NE of the Precambrian basement. It adapts to the vertical and lateral spread of tectonic stresses during lifting and re-mobilization of the different blocks of the base.

The short thermal Carboniferous event dated by fission track on zircons from the Precambrian basement, followed by rapid cooling (Sebti et al. 2009), support an attribution to Hercynian (orogeny) folding followed by erosional exhumation. The shortening is also shown by the soft folding of the cover with a clear involvement of the basement with a direction that changed over time from NW-SE to N-S.

\subsection{Seismicity}

Potential seismic hazard in the Amtoudi region is a possibility to take into account for a geological-risk evaluation. The main seismic sources come from distant Atlantic Ocean and western High-Atlas seismic sources. Examples include earthquakes on March 15th, 1964 and the February 28th, 1969 in the Atlantic Ocean with observed intensities III and V MSK-64, respectively, in the Amtoudi region, as well as the Agadir earthquake of February 29th, 1960 with observed intensity V MSK-64 in this region (Cherkaoui 1991). 
The seismicity map of Morocco for the period 1901-2012 shows the western and eastern High Atlas and the Anti-Atlas characterized by a low seismic activity (Cherkaoui and El Hassani, 2012), although with exceptions such as observed by the aforementioned destructive 1960 Agadir earthquake ( $=X$ MSK-64, $m_{b}=5.9$ ) (Cherkaoui 1988; Cherkaoui et al. 1991). Seismicity follows the general direction NE-SW of the Atlas Mountains and associated structures.

Regional earthquake magnitudes do not generally exceed $M_{w}=4.0$, with the exception of one event $\left(M_{w}=4.1\right)$ located $50 \mathrm{~km}$ north-west from Amtoudi. The largest Anti-Atlas earthquakes were recorded on the eastern end (e.g. the Rissani earthquakes on October, 23rd and 30th $1990, M_{w}=5.2$ and 5.3 , respectively). The seismicity is essentially rather superficial (depth $\leq 33$ $\mathrm{km}$ for more than $85 \%$ of cases) following the general direction NE-SW of the Atlas structures. In the absence of significant earthquakes $\left(M_{w} \geq 5.0\right)$, no focal mechanism could be determined for the Anti-Atlas except in the easternmost part (Bensaid et al. 2011).

In this region, where seismic hazard is low, the maximum horizontal ground acceleration values of the bedrock do not exceed $0.06 \mathrm{~g}$ (Jiménez et al. 1997; Giardini et al. 2003). Certainly, more exhaustive research would be useful. For instance, detailed investigations of active faults in the region are recommended and microearthquake monitoring would be helpful in this effort.

\section{Data acquisition and tests}

\subsection{Geology}

At the basin scale, the main geological characters and tectonic structures are reported in Figure 2B. As elsewhere the stratigraphy of the Amtoudi region is characterized by: (i) Precambrian basement divided into different successions and separated by major unconformities (Choubert 1963; Naidoo et al. 1991; Ennih and Liegeois 2001); and (ii) Palaeozoic sedimentary cover slightly deformed during the Hercynian orogenesis. A Palaeozoic suite covers the Precambrian basement by a transgressive marine succession that widely outcrops in southern Morocco. The thickness of the Palaeozoic stratigraphic record may exceed $10 \mathrm{~km}$ in the westernmost Anti-Atlas (Tiznit region) but can be less than $5-6 \mathrm{~km}$ in the easternmost Anti-Atlas (Tafilalt region) (Burckard et al. 2006; Soulaimani and Burckard 2008). Synthetic stratigraphic columns and chronostratigraphy of the Proterozoic basement and Palaeozoic sedimentary cover of the Anti-Atlas is furnished by Burckard et al. (2006) and Soulaimani and Burckard (2008), to which we will refer.

A lithostratigraphic study was deemed necessary to characterize the construction materials and the geologic basement of the agadir because the stones used for its building and fortification come from the local succession. The litho-stratigraphy in the Amtoudi area was reconstructed by three logs (Fig. 3). Logs were measured and sampled to identify the main rocks used to build the agadir (Table 2). 
Log 1 starts at the base of the agadir hill and includes the beds outcropping inside of the agadir $\left(9.1847^{\circ} \mathrm{N}, 29.2459^{\circ} \mathrm{W}, 105 \mathrm{~m}\right.$ thick). Log 2 was measured along the hill just to east of that of the agadir $\left(9.1835^{\circ} \mathrm{N}, 292461^{\circ} \mathrm{W}, 110 \mathrm{~m}\right.$ thick). Log 3 reconstructs the succession inside of the main valley just south of the village $\left(9.1538^{\circ} \mathrm{N}, 29.2418^{\circ} \mathrm{W}, 60 \mathrm{~m}\right.$ thick). The successions measured belong to the southern flank of a syncline with approximately $\mathrm{N} 70^{\circ}$ axis direction and structurally between two anticlines.

The results from petrographic analyses of samples taken in Log 1 are reported in Table 2. The synthetic succession has been subdivided into four main stratigraphic intervals characterized by different litho-petrofacies associations:

(1) Interval A (logs 1 and 2; Fig. 3) constitutes the lowest portion of local succession with thicknesses of over $25 \mathrm{~m}$ and is dominant in the Amtoudi area. It consists of brownish recrystallized limestones (wackestone/grainstone) characterized by massive, detritic, silicified, dolomitized limestones with lamination, asymmetric ripples and irregular stratification; thickness is between 0.1 to $1.5 \mathrm{~m}$. Colour variations have been observed and they correspond to size changing (from very fine to sandy) of grains.

(2) Interval B (Logs 1, 2, and 3; Fig. 3), prevalently claystones/siltstones, is characterized by darkish micaceous argillites, stratified, laminated, and silicified with massive dark-brownish arenites and siltstones interbedded. Three clearly distinguishable beds of wackestones/ grainstones and some thin beds of very fine to coarser grey-green quartzarenites and of homogeneous silicified limestones are also present. Interval thickness is about $55 \mathrm{~m}$.

(3) Interval C (logs 1, 2, and 3; Fig. 3) immediately crops out under the agadir, constituting its geologic foundation. It consists of laminated arenites (arkosic sandstones) showing a bed varying in thickness from 1.0 to1.5 m. These arenites are greyish-greenish in colour, from massive to thinly stratified, very fine-grained and often covered with a black patina: they show great hardness due to the siliceous composition. Laminated beds with chaotic, heterogeneous whitish pelites are also interbedded. The interval thickness is about $25 \mathrm{~m}$. Fe-Mn mineralizations and glauconie have been observed.

(4) Interval D (logs 1, 2, and 3; Fig. 3) is prevalently detected inside of the agadir for a thickness over $12 \mathrm{~m}$. It starts with blackish and purple stratified schists, with schistosity evidenced by diffusion of the brightest flakes of mica surfaces, fine-grained, and centimetric in thickness; pyrite is quite common. This is followed by an alternation of previous petrofacies as: wackestones/grainstones, claystones/siltstones and arkosic sandstones.

Fig. 3 
Field and petrographic observations confirm the attribution to the middle Cambrian, over the Adoudounian Group (Soulaimani and Burckard 2008). The lithofacies indicate a shelf deposition with additional fine detritic supply coming from Saharan domain as reported by Burckard et al. (2006).

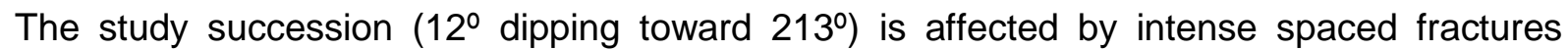
grouped in three main sub-vertical jointing systems oriented $\mathrm{N} 150^{\circ}, \mathrm{N} 100^{\circ}$, and between $\mathrm{N}-\mathrm{S}$ and $\mathrm{N} 20^{\circ}$. Small normal faults (shift around $50 \mathrm{~cm}$ ) with $\mathrm{N} 140^{\circ}$ direction are also present.

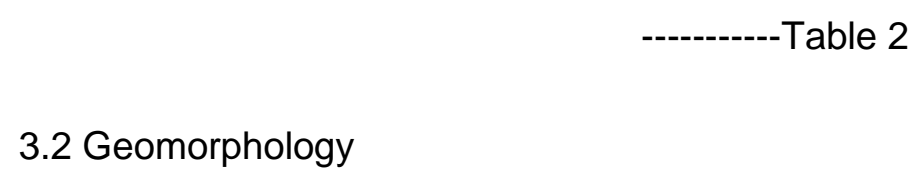

\subsection{Geomorphology}

The valley of the Amtoudi village is surrounded by relief exceeding $100 \mathrm{~m}$, such as the Kerdous Precambrian buttonhole. Relief extends towards the ESE in a canyon with steep slopes and lateral walls overlooking the bottom of the Wadi des Argan, which is landlocked. The relief shows a lithological control marked by the hard rocks. Carbonates and archeociatid bioherms make up the cliffs in the Amtoudi Agadir and village area. Carbonates also show an incipient karstification favoured by the bioherm porosity.

A geomorphologic map of the area (Fig. 4) was drawn to include the classification of slopes, contacts, drainage network, and additional elements such as fallen blocks, oasis, and human settlements. The agadir is located on a high slope area with fallen blocks and is affected by gullies of the secondary drainage network. The main risks are gravitational and flooding processes in addition to the seismicity or the area as a detonation factor. The absence of clayish and gypsum rocks removes the possibility of halokinetic risk.

\subsection{Geotechnics: the Amtoudi massif}

The Amtoudi Agadir massif has a pinnacle shape $150 \mathrm{~m}$ in elevation. It is assumed that natural slope of the shape resulted from geomorphologic and tectonic forces. Five natural slopes were identified (Fig. 5): Slope 1 N133E and N223E facing, Slope 1' N133E and N043E facing, Slope 2 N046E and N136E facing, Slope 2' N046E and N316E facing, and Slope 3 N017E and N107E facing. Slopes are characterized by the interval C (arkosic sandstones).

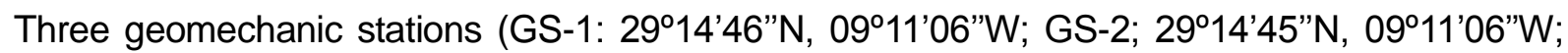
and GP-3: $29^{\circ} 14^{\prime} 47^{\prime \prime} \mathrm{N}, 09^{\circ} 11^{\prime} 05^{\prime \prime} \mathrm{W}$ ) were implemented in the agadir and surroundings (Fig. 5) for 72 in situ measurements of massif rock unconformity systems, as well as for 72 rebound 
measurements with a smith hammer. Three tilling tests were performed, one at each geo-mechanic station.

An uniform N123E main stratification (S) and 12 dipping towards N213E was measured. Three main jointing systems were identified (J1: 78/024, J2: 89/280, and J3: 82/050) with different geomechanical properties (Table 3).

Additionally, rocks were sampled for testing in Cehegin Marble Technologic Center Lab (Murcia, Spain) and Ground Engineering Lab at Alicante University (Alicante, Spain). The analyses consisted on 10 samples for uniaxial compression-resistance tests (s/UNE 22950-1) giving 191.5 Mpa, 13 samples for breaking-point load resistance (s/UNE 22950-5) giving $5.6 \mathrm{Mpa}, 12$ samples for a $0.19 \%$ bulk rock porosity (s/UNE - EN 1936), and 31 samples testing for specific weight (s/UNE - EN 1936) giving $26.5 \mathrm{KN} \mathrm{m}^{-3}$.

(1)

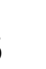

fre

frot
from Bienniawski (1989), Q from Barton et al. (1974), and SMR from Romana (1997). For the massif the results were: Class II (good quality) after RMR (70 points) and, as RQD = 100\% and Group 2 (25 points) from Barton (good quality). Data provide mean values of $25 \mathrm{kPa}$ cohesion and 38\% angle of internal friction. When RMR and SMR classifications were applied taking the slope orientations into account, slopes 1 (mainly), 1' and 3 showed problems of stability (Table 4). In the Discussion section, the stability estimation for worst-case scenario (Slope 1) will be explained.

\begin{abstract}
-Table 4---------

\subsection{Architectonic diagnosis of Amtoudi Agadir}

The original construction style of Amtoudi Agadir and the successive repairs have been performed with the traditional materials and constructive techniques in the area, consisting basically of harnessing environmental resources. Therefore, the materials used consisted of local rocks and scarce clays, lime (made by artisan procedures of roasting carbonate rocks), basic clay-based mortars, argan and palm wood for the ceiling structures and carpentry.

Data from the different architectonic elements, materials used and existing failures were recorded in order to assess the stability of Amtoudi Agadir. Specifically, in order to perform concrete calculations on the ceiling-structure safety, the SE tower of the agadir was sketched (see Fig. 6).
\end{abstract}


-Fig. 6

\subsubsection{Load-bearing structural elements.}

These elements support a certain pressure, the following being found in the agadir:

- Gravity walls. Usually appearing on the exterior sides of the agadir, are made up of the accumulation of stacked flat rock fragments. These walls lack interlocking joints in the masonry, have no mortar, and in some cases resemble a small, rough ashlar. The dimensions (height and thickness) are a meter or two (Fig. 7a)

- Buttresses. In some places of the exterior sides of the agadir, gravity walls or towers are buttressed (Fig. 7a) and are also composed of stacked flat rock fragments in a similar way to gravity walls.

- Load-bearing walls. These (Fig. 7b) are used to partition rooms and to support the ceilings, the vast majority of the load-bearing structural elements being in the interior of the agadir. These, like the external walls, are built by stacking flat rock fragments, but in this case joined by a clay and lime mortar. These walls usually measure 0.30 to $0.50 \mathrm{~m}$ thick and less than o $3 \mathrm{~m}$ high. - Isolated pillars. These, much less frequent in the agadir, support part of the ceiling load, allowing the circulation within the enclosed space. These isolated pillars in some cases consist of piers (Fig. 7c) and in some others are columns made of a monolitic prismatic stone with centrimetric diameters (Fig. 7d).

Fig 7

\subsubsection{Supported structural elements}

These elements rest on the load-bearing structural elements working by flexure under the pressure; the following are found in the agadir:

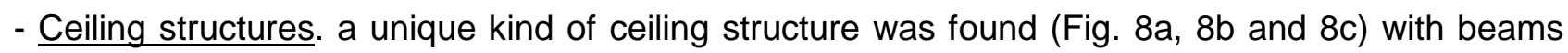
resting on the load-bearing walls and flat stones over the beams or interlaced palm leaves (Fig. 8a, $8 \mathrm{~b}$ and $8 \mathrm{c}$ ). These structures, over the flat stones, usually carry a gravelly fill topped by a thin layer of mortar made of clay and lime. This layer is of better quality and thicker in the roof structure (Fig. 9d).

- Lintels. These, appearing over the openings in the walls for windows and doors, consist of sturdier beams embedded in the wall. These beams, meant to support the weight of the wall above the opening of the door or window, are made of solid argan timber or stone, both square in section and having a width reaching $20 \mathrm{~cm}$. 
Fig. 8

\section{Risk assessment}

Taking into account all the above data and tests, we now assess the main risk factors affecting the Amtoudi Massif and Agadir.

\subsection{External geological processes}

The Amtoudi Massif is located on subtropical dry semiarid climate with a bimodal precipitation distribution, in a zone with a steep slope, mainly affected by gravitational and climatic processes.

The most of the precipitation occurs during the autumn and spring with erratic events of high spatiotemporal heterogeneity. The most negative climatic influence is the extreme daily rainfall events that can reach around $50 \mathrm{~mm}$ per day. Under such extreme rainfall, the Amtoudi Massif becomes water-saturated, the pores and cracks of the massif being filled with water. This provides an additional load to the ground and lubrication favouring gravitational processes (landslides). In the calculation of stability of the slopes of the massif, this possibility of water saturation will be taken into account.

The geomorphologic map drawn for the area (Fig. 4) includes slopes (low, middle and high), geomorphologic contacts (concave or convex, progressive or rupture), main and secondary drainage network, and such geomorphologic elements as fallen blocks. These aspects are closely related to the geological risk, making it clear that the agadir site, located on a high slope with fallen blocks, is affected by gullies of the secondary drainage network. The absence of clayish and gypsum rocks removed the possibility of halokinetic risk, though risks related to gravitational and fluvio-alluvial processes remain.

The possible interference and influence of these factors (Climate and landscape) must be taken into account for calculations of stability of the massif and agadir. In the following sections these influences will be estimated by combination of them.

\subsection{Internal geological processes influence}

On the basis of the geological survey (mapping, stratigraphy, and petrographic determination), certain internal geological risks should be considered due to the spatial distribution of the geological bodies, geometric arrangement of the beds, and kind and arrangement of the jointing affecting the massif, since the types of rocks involved are of very good quality. The basement of the agadir consists of the interval C, made of stratified greyish- 
greenish arenites (arkosic sandstones showing high hardness due to the siliceous composition). Nevertheless, this level is affected by a sub-vertical jointing and a stratification dipping $12^{\circ}$ towards N213E. These aspects favour instability processes in some preferential orientations, as will be treated below. In the interior of the agadir the interval $D$ crops out, this made up of stratified schists and an alternation of arenites as wackestone/grainstone, claystone/siltstone and arkose/subarkose. For the construction of the agadir, the arenite blocks and flat stones were preferred. These rocks are usually quite resistant, although, in some cases, when the specimens chosen are very flat, damages occurs, as it will be explained below.

The regional earthquake magnitude is low $\left(M_{w}<4.5\right)$, since the Anti-Atlas area shows low seismic activity but not null. In the area a low seismic acceleration of $0.06 \mathrm{~g}$ should be included in the calculation of stability and of constructions. This value of $0.06 \mathrm{~g}$ weakly affects calculations, as will be discussed below, but an earthquake can function as an accelerator of other risk processes, such as gravitational problems. Moreover, in the case of the agadir, architectonic elements with troubles can be totally destroyed.

The possible interference and influence of the internal and external geological factors should be taken into account for calculations of the stability of the massif and agadir. In the following sections, these influences will be estimated by combination of them.

\subsection{Stability of Amtoudi Massif}

As mentioned above, slopes 1, 1', and 3 show problems of stability. Nevertheless, since stratification faces $12^{\circ}$ towards N213E, only slope 1 can cause the sliding of large blocks (larger than 5-10 m). The stratification affects mainly to Slope 1 since the other slopes show different orientations and facings. In the other cases (Slopes 1' and 3), the dips of jointings are sharply vertical, encouraging instability but only for small blocks (centimetric to decimetric slabs or pins) the risk being minor and thus requiring a simple treatment (anchored meshes) for stabilization. Therefore, a stability study on the worst-case scenario (slope 1) has been performed using the model of critical stability with planar break with the software of equilibrium limit (RockPlane v2.0 from Rocscience Inc., licensed no 4416A), considering several possibilities.

This kind of calculation is valid when there are dominant unconformities in the massif oriented with a negative bearing with the slope orientation. In our former study, four unconformity systems were defined, including stratification and jointing ( $\mathrm{S}, \mathrm{J} 1$, J2, and $\mathrm{J} 3$ ). In the case of Slope 1, J1 and J3 favour tension cracks, J2 individualize blocks, and S acts as a sliding surface (Fig. 9). Once the possibility of the block to slide is determined and with the use of data from the geo-mechanic station (orientation, dipping, roughness, spacing, aperture, fillings, weathering degree, wetting), and laboratory analyses (specific weight, open porosity, compressive resistance, breaking-point load resistance, cohesion, density, angle of internal friction) the calculation was performed following the Barton standard enclosure procedure (Barton, et al. 1974) for block heights of 5 and $10 \mathrm{~m}$. 
Fig. 9

3

Calculations were made under three hypotheses: gravitational, gravitational and seismic $(0.06$ $\mathrm{g}$ ), and gravitational with water saturation (the hypothesis of seismic and water saturation was ruled out as highly unlikely). Although when the studies were performed when the massif conditions were dry, the climatic possibility of rains with extreme daily rainfall events of around $50 \mathrm{~mm}$ per day was taken into account, the calculation with water saturation was deemed highly pertinent. On the other hand, water saturation was also considered with two variants: with drainage by the sliding surface or without drainage (when unconformity surfaces of the massif are filled by sediments).

Table 5

Taking into account a safety factor below 1 signifies instability, the slope studied shows troubles of planar sliding under gravitational and water-saturation conditions if the massif is not drained.

\subsection{Analysis of the architectonic elements of the Amtoudi Agadir}

Some calculations to assess the safety of the ceiling structures were performed taking as an example the SE tower (sketched above) of the Amtoudi Agadir in the worst-case scenario (when beams are made of palm wood). The input data are the following:

- weight of the ceiling structures: $5.0 \mathrm{kN} / \mathrm{m} 2$ (flat stones: $0.8 \mathrm{kN} / \mathrm{m} 2$; gravel (crushed gravel): 3,15 $\mathrm{kN} / \mathrm{m} 2$; palm beams: $0.1 \mathrm{kN} / \mathrm{m} 2$; clay and lime: $0.95 \mathrm{kN} / \mathrm{m} 2$ )

- mean spacing of beams: $0.33 \mathrm{~m}$

- mean length of beams: $2.35 \mathrm{~m}$

- mean cross-section of beams: $57.7 \mathrm{~cm} 2$;

- mean moment of inertia of joists: $236 \mathrm{~cm} 4$;

- flexural elastic modulus of the palm: $2,900,000 \mathrm{kN} / \mathrm{m} 2$;

- overload: $2.0 \mathrm{kN} / \mathrm{m} 2$;

- Palm failure stress according to Ratanawilai et al., (2006):

o traction (direction parallel to the fibres): $43,250 \mathrm{kN} / \mathrm{m} 2$

o compression (direction parallel to the fibres): $23,650 \mathrm{kN} / \mathrm{m} 2$

o shear (direction transverse to the fibres): $850 \mathrm{kN} / \mathrm{m} 2$

The above input data gives a total nominal load over the ceiling structure, including its own weight and overloads of $7.0 \mathrm{kN} / \mathrm{m} 2$. The safety check consisted of determining by standard procedures used in the theory of structures (Gere, 2004) the maximum traction and compression due to bending of the joists, as well as the maximum shear stress at the supports. These tensions have 
been compared with breaking stresses of the beams under the corresponding efforts. With this calculation, a safety factor is established. According to the usual safety criteria, of values below 1.5 imply risk of failure.

For the calculation, two conditions were changed (Fig. 10): (1) the load over the ceiling structure was progressively increased up to 10-fold the normal value (left part of Fig. 10); (2) the performance of the material of the beam was reduced (right side of Fig. 10) due to rot, insect attack, or material fatigue (= reducing the flexural elastic modulus).

Fig. 10

In the first case (when the load is increased) behaviour in the three cases (traction, compression or share) is similar, and beyond 0.6 -fold the normal value, the safety factor falls below 1.5 , evidencing problems in case of seismicity or torrential rains. Up to double the normal value, the safety factor is below 1 with the collapse of the structure.

In the second case (when the flexural elastic modulus of the palm is reduced by rot, insect attack, or material fatigue) the behaviour in the three cases (traction, compression or share) is different, shearing being the worst situation. In the case of shear, when a reduction of a $20 \%$ in performance occurs, the safety factor falls below 1.5 . When the reduction is about $50 \%$, the safety factor is below 1 . The other two cases (compression and traction) show similar trends, the safety factor going below 1.5 for a reduction of a $40 \%$ in the performance of the material, and below 1 for a reduction of a $60 \%$.

The most important failures that can be observed in Amtoudi Agadir occur on the structural walls and on the beams of the ceiling structures. In both cases the problems are due to poor construction and maintenance, as explained in Table 6 and depicted in Figure 11.

\section{Conclusions and propositions}

\subsection{Main results}

(a) Amtoudi Agadir is located in a subtropical dry semiarid climate with a bimodal precipitation distribution. The most negative climatic influence is the possibility of an extreme daily rainfall event of around $50 \mathrm{~mm}$, providing additional loads to the ground and lubrication, favouring gravitational processes (landslides) and/or erosion in the substratum.

(b) The sector of the Anti-Atlas considered shows low seismic activity, making it necessary to consider a seismic acceleration of $0.06 \mathrm{~g}$ to calculate the stability. 
(c) The geological study reveals that the rocks of the underlying substratum of the agadir (Interval C; Fig. 3) and the stones used for its construction are good-quality arkosic sandstones. Nevertheless, certain geological risks due to the spatial distribution of the geological bodies, geometric arrangement of the beds, and kind and arrangement of the jointing affecting the substratum should be considered.

(d) Amtoudi Agadir is built on a rocky promontory with vertical cliffs with fallen blocks and affected by gullies of the secondary drainage network. Both elements indicate that risks for the substratum must be expected from gravitational and fluvial-alluvial processes.

(e) The mechanical tests made on the rocky matrix from the underlying massif reveal appropriate quality but the effect of three sub-vertical jointing systems (J1, J2 y J3) and stratification dipping $12^{\circ}$ towards N213E. The orientation of such unconformities mainly individualize minor blocks with slabs or pin morphologies (used in the ceiling structures) but when the strata are thick, blocks show prismatic morphologies (used in the walls). (f) Due to the shape and orientation of slopes, and characteristics of the jointing systems and stratification affecting the massif, landslides of large rock blocks or wedges are unlikely. Only Slope 1, when analysed with software of an equilibrium limit (RockPlane v2.0 from Rocscience Inc., licensed no $4416 \mathrm{~A}$ ) evidenced risk of instability under water saturation (corresponding to an

\subsection{Proposals}


(a) To ensure the stability of Slope 1, the following is recommended : (1) an appropriate watercollection system of the SW part of Agadir on the crown of Slope 1; (2) waterproofing the same area of the agadir to avoid infiltration in cracks and fissures; (3) sub-horizontal drainage boreholes with diameters greater than $70 \mathrm{~mm}$ in the slope rocks to evacuate water from slope and avoid water saturation.

(b) When the Slopes 1' and 3 cause only the instability of small blocks (centimetric to decimetric slabs or pins) the risk is minor, requiring only a simple treatment of anchored stabilization meshes.

(c) A downsizing of some walls is needed and bolstering the thinness with an improvement in the mortar and interlocking joints.

(d) In some of the worst cases, a bridging through ceiling structures is needed in some walls each $3 \mathrm{~m}$ of height to avoid long stretches of wall without support (weak under conditions of wind or earthquake).

(e) A review of certain ceiling structures is recommended: in some cases a higher number of beams is needed for a better weight distribution of the ceiling structure.

(f) To avoid troubles due to irregular geometry (curve) of the beams, the use of straight trunks for the beams is recommended. When possible, it is better to use stone than wood; when not, wooden beams that are warped, fractured, rotten, or attacked by insects should be replaced.

\section{Acknowledgements}

This research was supported by Urbino University found (Resp. F. Guerrera); by CGL2011-30153-CO202 and CGL2012-32169 research project (Spanish Ministry of Education and Science) and by Research Groups and projects of the Generalitat Valenciana from Alicante University (CTMA-IGA). We would also like to thank the Research Unit associated with CNRST (URAC 46), Scientific Institute and Mohammed V University, Morocco, for logistical support and equipment for field work and sampling. The authors are very grateful to a native speaker (David Nesbitt) for improving the English version of the manuscript.

\section{References}

Arora V K (2002) The use of the aridity index to assess climate change effect on annual runoff. Journal of Hydrology 265:164-177.

Barton N, Lien R, Lunde J (1974) Engineering classification of rock masses for the desing of tunnel support. Rock Mechanics. Springer Verlag 6:89-236.

Bensaid I, Cherkaoui T E, Medina M, Caldeira B, Buforn E, Emran A, Hahou Y (2011) The 1992 Tafilalt seismic crisis (Anti-Atlas, Morocco). J Seismol, DOI: 10.1007/s10950-011-9248-5.

Bieniawski Z T (1989) Engineering rock mass classifications. John Wiley and Sons, 251 pp. 
Born K, Fink A H, Paeth $\mathrm{H}$ (2008) Dry and wet periods in the northwestern Maghreb for present day and future climate conditions. Meteorologische Zeitschrift. 17:533-551.

Burkhard M, Caritig S, Helg Robert-Charrue Ch, Soulaimani A (2006) Tectonics of the Anti-Atlas of Morocco. Comptes Rendus Géoscience, 338:11-24.

Cherkaoui T E (1988) Fichier des séismes du Maroc et des régions limitrophes : 1901-1984. Trav. Inst. Scien., Série géol. géogr. phys. 17. Rabat, 158pp., + carte h. t.

Cherkaoui T E (1991) Contribution à l'étude de l'aléa sismique au Maroc. Ph.D. thesis, Joseph Fourier University, Grenoble.

Cherkaoui T E, El Hassani A (2012) Seismicity and Seismic Hazard in Morocco: 1901-2010. Bulletin de l'Institut Scientifique, Rabat, section Sciences de la Terre, 34:45-55.

Cherkaoui T E, Medina F, Hatzfeld D (1991) The Agadir earthquake of February 29, 1960. Examination of some of the parameters, in: Seismicity, seismotectonics and seismic risk of the iberomaghrebian region. Monografia n`8, Inst. Geogr. Nacional, Madrid, 133-148.

Choubert G (1963) Histoire géologique du Précambrien de l'Anti-Atlas. Notes et Mém. Serv. géol. Maroc, 162.

Chow V T, Maidment D R, Mays L W (1988) Applied hydrology. McGraw-Hill, New York. 588pp.

Dunham R J (1962) "Classification of carbonate rocks according to depositional texture". In Ham W.E. "Classification of carbonate rocks", American Association of Petroleum Geologists, Memoir, 1:108-121.

Ennih N, Liégeois J P (2001) The Moroccan Anti-Atlas: The West African Craton passive margin with limited Pan-African activity. Implications for the northern limit of the craton. Precambr. Resear. 112:289-302.

Fettes D, Desmons J (2007) "Metamorphic rocks. A Classification and Glossary of Terms. Reccommendations of the International Union of Geological Sciences Subcommission on the Systematics of Metamorphic Rocks". IUGS, Cambridge University Press: 244pp.

Gasquet D, Ennih N, Liégeois J P, Soulaimani A, Michard A (2008) The Pan-African Belt, in : Michard, A., Saddiqi, O., Chalouan, A., de Lamotte, F. (Eds.), Continental evolution : The Geology of Morocco, Lecture Notes Earth Sci. 116, Springer-Verlag, Berlin, Heidelberg, 33-64.

Gazzi P, Zuffa GG, Gandolfi G, Paganelli L (1973) "Provenienza e dispersione litoranea delle sabbie delle spiagge adriatiche fra le foci dell'Isonzo e del Foglia: inquadramento regionale". Mem Soc. Geol. Ital. 12:1-37.

Gere J M (2004) Mechanic of materials. Thomson Learning, Inc. (Sixth Edition). 964 pp.

Giandotti M (1934) Previsione delle piene e delle magre dei corsi d'acqua. Memorie e studi idrografici. Pubbl. 2 del Servizio Idrografico Italiano 8:107pp. 
Giardini D, Jiménez M J, Grünthal G (2003) The ESC-SESAME unified seismic hazard model for the European-Mediterranean region. European Seismological Commission/UNESCO-IUGS International Geological Correlation Program. Project n 382, SESAME.

Jiménez M J, García Fernández, y Grupo de Trabajo Íbero-Magrebí (GSHAP: Hammed Chadi M, El Foul D, Izquierdo A, Martínez Solares J M, Sousa Oliveira C, Aissa Tadili B (1997) "Evaluación del riesgo sísmico en la región Íbero-Magrebí".

Naidoo DD, Bloomer SH, Saquaque A, Hefferan KP, (1991) Geochemistry and significance of metavolcanic rocks from Bou Azzer-El Graara ophiolite (Morocco). Precambr. Res., 53, 79-97.

Naji S (2003) Greniers collectifs de l'Atlas. Patrimoines du Sud marocain. Etitions Edisud et Editions La croisée des Chemins (Casablanca, Maroc), ISBN 9981-896-89-6, 299 pp.

Ratanawilai T., Chumthong T, Kirdkong S, (2006) An investigation on the mechanical properties of trunks of palm oil tres for the furniture industry. Journal of Oil Palm Research, 18, 114-121.

Romana, M. (1997): El papel de las clasificaciones geomecánicas en el estudio de la estabilidad de taludes. In: "IV Simposio Nacional sobre taludes y laderas inestables. Comunicaciones“, 3: 9551011.

Schulz O (2008) Precipitation in the Upper and Middle Drâa basin. In: Schulz, O. and Judex, M. (eds.): IMPETUS Atlas Morocco. Research Results 2000-2007. Department of Geography, University of Bonn, Germany.

Sebti S, Saddiqi O, El Haimer F-Z, Michard A, Ruiz G, Bousquet R, Baidder L, Frizon De Lamotte D (2009) Vertical movements at the fringe of the West African Craton : First zircon fission track datings from the Anti-Atlas. Precambrian basement, Morocco. C. R. Geoscience 341:71-77.

Soulaimani A (1998) Interactions socle/couverture dans I_Anti-Atlas occidental (Maroc) : rifting finiproterozoïque et orogenèse hercynienne, Thèse Doct., Université Marrakech, Maroc, 215pp.

Soulaimani A, Burkhard M (2008) The Anti-Atlas chain (Morocco): the southern margin of the Variscan belt along the edge of the West African Craton, in : Ennih, N., Liégeois, J.-P., (Eds.), The boundaries of the West African Craton. Geol. Soc, London, Spec. Publ. 297:429-448.

Témez JR. (1978) Cálculo hidrometeorológico de caudales máximos en pequeñas cuenca naturales. MOPU. Dirección General de Carreteras, Madrid. 113pp. (in Spanish)

U.S. Bureau of Reclamation (1973) Design of Small Dams. 2nd ed., Washington, D.C.

Wentworth C K (1922) A scale of grade and class terms for clastic sediments. Journal of Geology 30: 377-392. 


\section{Figure and table Captions}

Fig. 1 - Photographic documentation of the Amtoudi area (village, oasis and agadir). A, Amtoudi village and oasis (view from the agadir); B, southwest view of the agadir from the Amtoudi village; $\mathbf{C}$, close west view of the agadir from the Amtoudi village; $\mathbf{D}$, southeast view of the sidewall of the agadir; $\mathbf{E}$, northwest close view of the agadir; $\mathbf{F}$, internal aspect of the agadir.

Fig. 2 - A, Geological sketch map of the western Anti-Atlas Chain in the Moroccan Atlas system; B, Geological map and cross-sections of the Amtoudi area.

Fig. 3 - Stratigraphy of the logs reconstructed near Amtoudi agadir and village. a, brownish silicified and dolomitized limestones (wackestones/grainstones); b, micaceous argillites (claystones/ siltstones); c, thin greenish quartzarenites; d, probably tuffaceous marker-bed; e, homogeneous silicified limestones (wackestones/grainstones); f, micaceous arenites (arkosic sandstones); g, blackish schistes.

Fig. 4 - Geomorphological map and cross-sections of the Amtoudi area.

Fig. 5 - A, main slopes and unconformity systems of the Amtoudi agadir massif; B, plot of jointing directions; $\mathbf{C}$, plot of poles density of unconformity surfaces.

Fig. 6 - SE tower of the Amtoudi Agadir. Front and side views photos (left side), and sketches views of front, side and top ceiling structure (right side).

Fig. 7 - Load-bearing structural elements in the Amtoudi Agadir: a) exterior walls and buttresses; b) load-bearing walls; c) masonry pier; d) stone column.

Fig. 8 - Supported structural elements in the Amtoudi Agadir: a) palm ceiling structure; b) ceiling structure with flat stones; c) ceiling structure of mixed materials; d) roof structure.

Fig. 9 - Stability simulation: role of S, J1, J2 and J3.

Fig. 10 - Safety factor evolution curves by increase of overload over the ceiling structures (left) and reduction of the performance of palm wood (right).

Fig. 11 - Failures of ceiling structures and walls in the Amtoudi Agadir: a, ceiling structure with bent or sheared beams (see arrow); b. Detail of sheared stone beam due to excess of load; c, Detail of argan wooden beam sheared by flexure due to excess of load; $\mathbf{d}$, ceiling structure with palm beam sheared by flexure; e, buckled walls having curved surfaces (see arrows) due to being 
1 too thin; $\mathbf{f}$, tension crack due to lack of interlocking joints in the masonry or lack of mortar locking

2 the stones.

3

4 Table 1 - Expressions used to evaluate the concentration time ( $\mathrm{T}$ ) of the "Wadi des Argan"

5 hydrological basin.

6

7 Table 2 - Main petrofacies recognized in the study area and micro-photographic documentation.

8 Petrographic classification according to Wentworth (1922) (claystones/siltstones); Fettes and

9 Desmons (2007) (schist); Gazzi et al. (1973) (arkosic sandstones), and Dunham (1962)

10 (wackestones/grainstones).

11

Table 3 - Geo-mechanics properties of the unconformity systems affecting the Amtoudi massif.

13

14 Table 4 - Classification of the Amtoudi massif according to the slope orientation.

15

16 Table 5 - Safety factors for planar sliding model.

17

18 Table 6 - Failures of the architectonic elements in the Amtoudi Agadir.

19 
Click here to download high resolution image
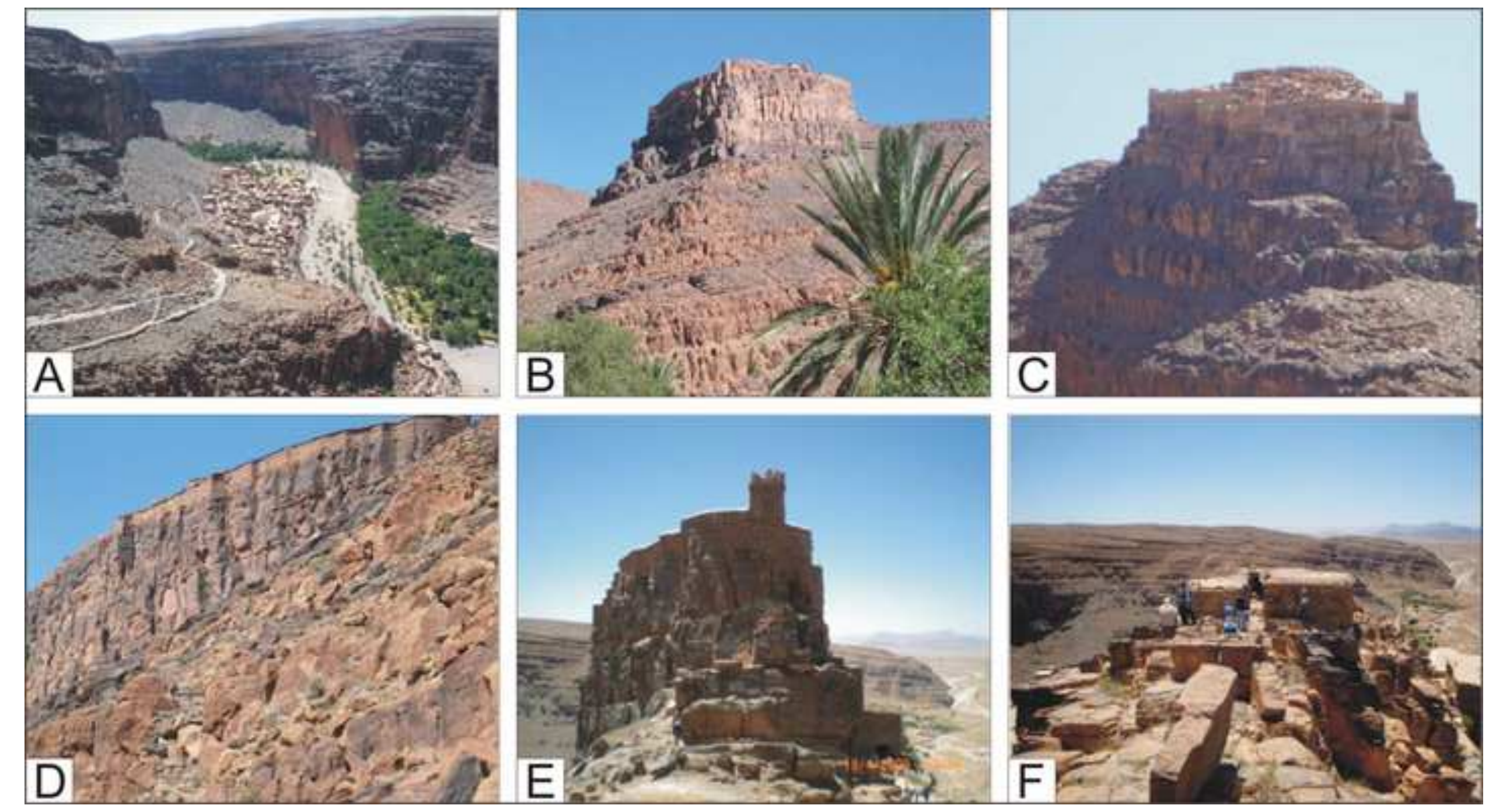


\section{Figure 2}

Click here to download high resolution image
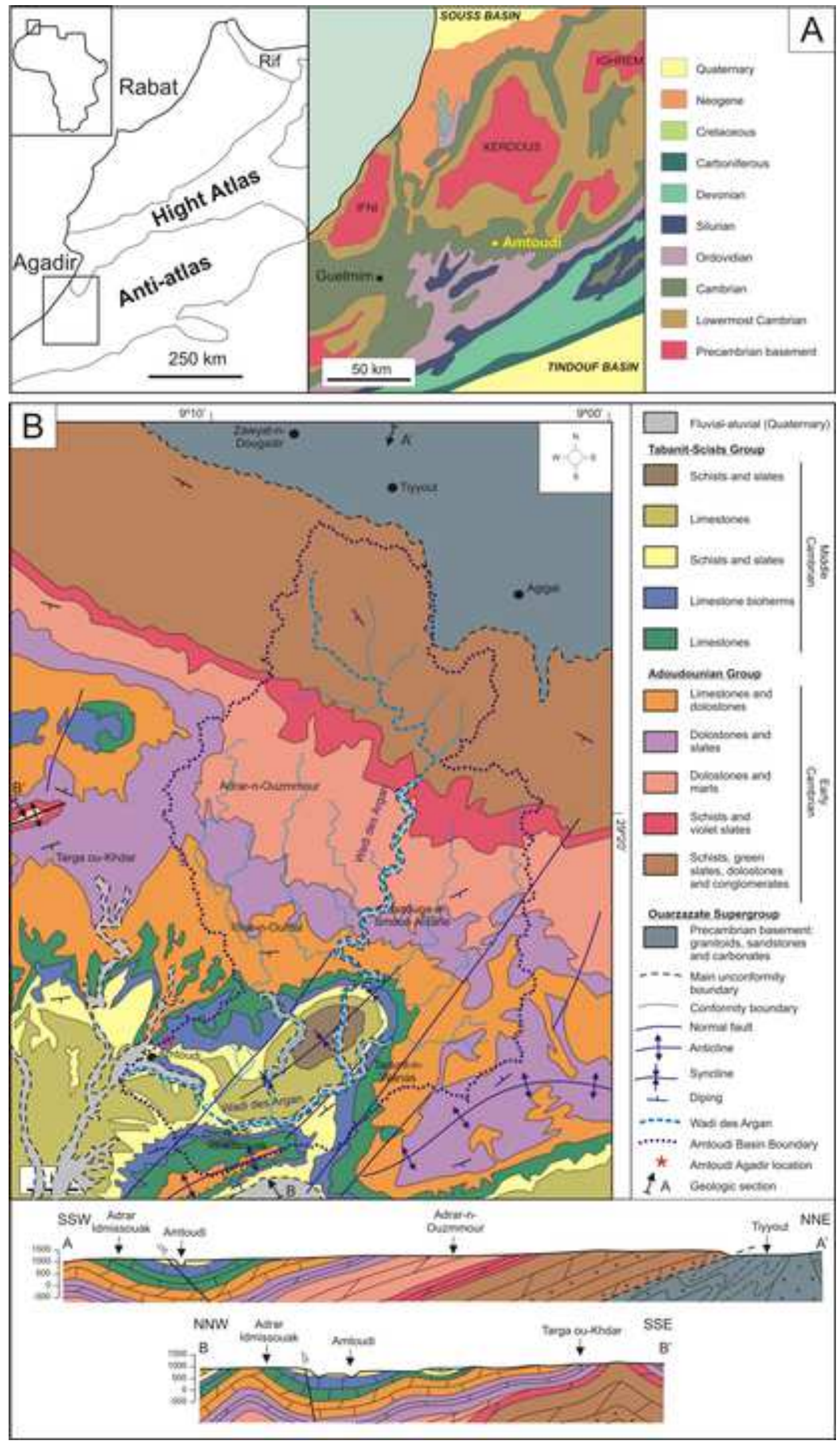


\section{Figure 3}

Click here to download high resolution image

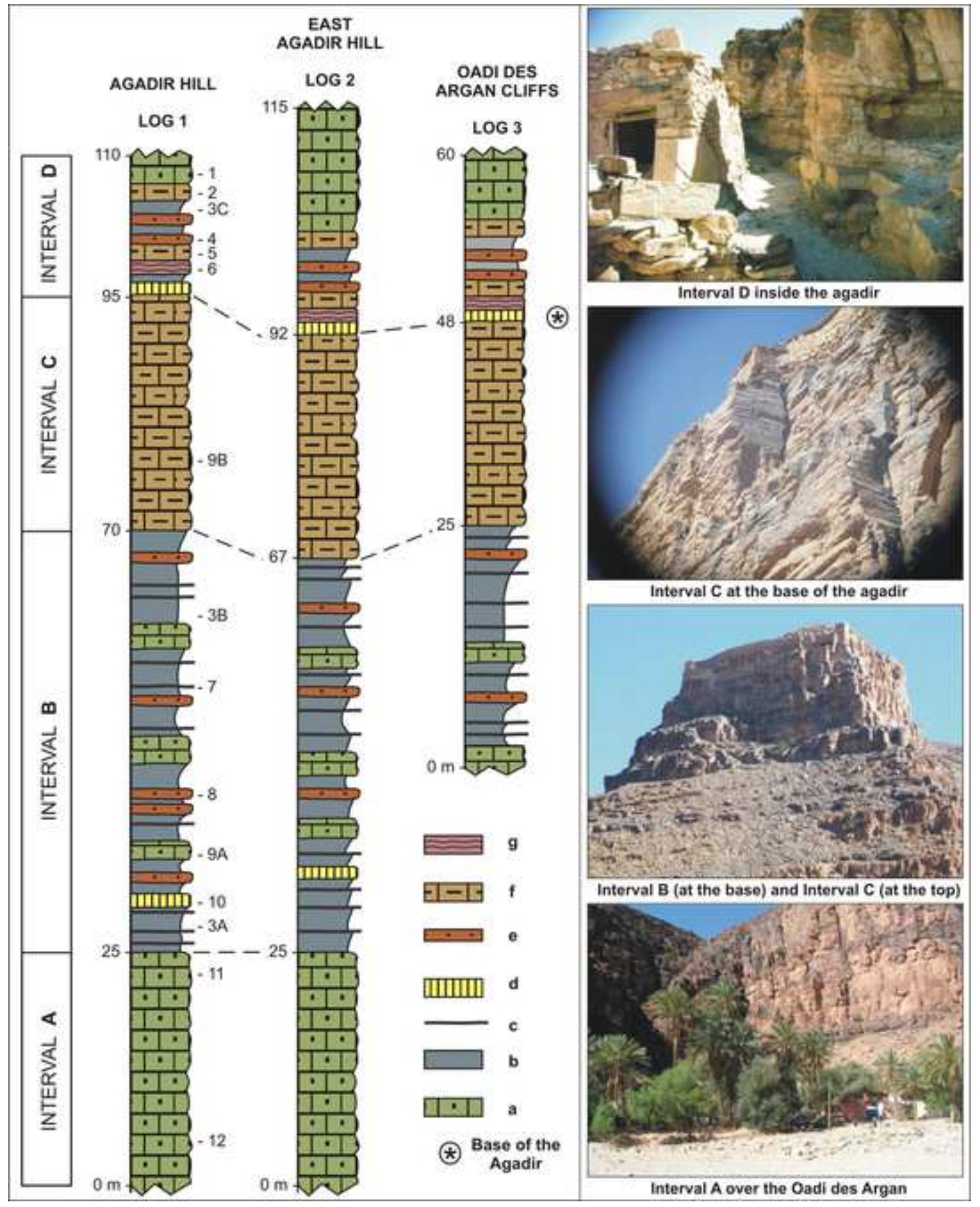




\section{Figure 4}

Click here to download high resolution image

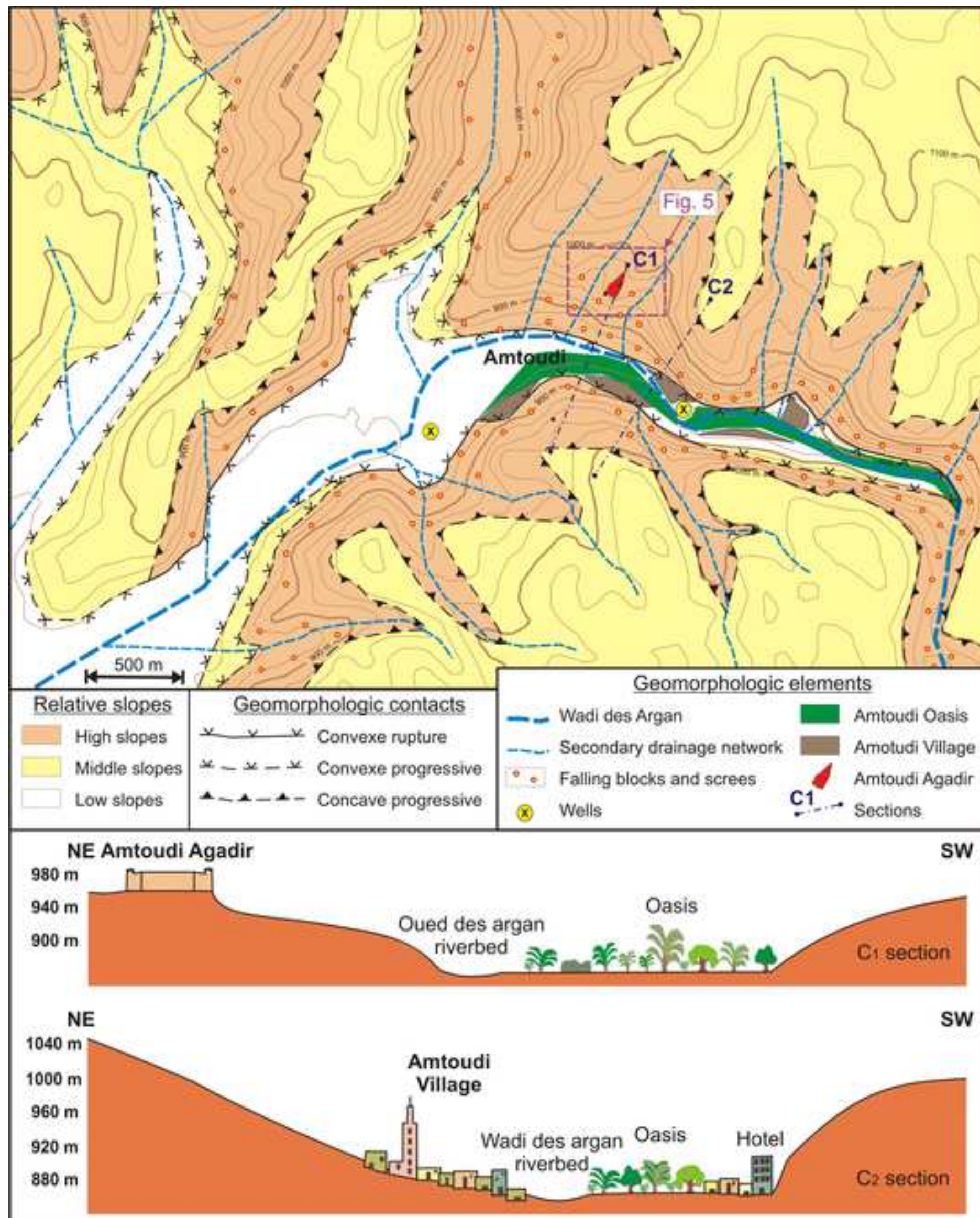




\section{Figure 5}

Click here to download high resolution image

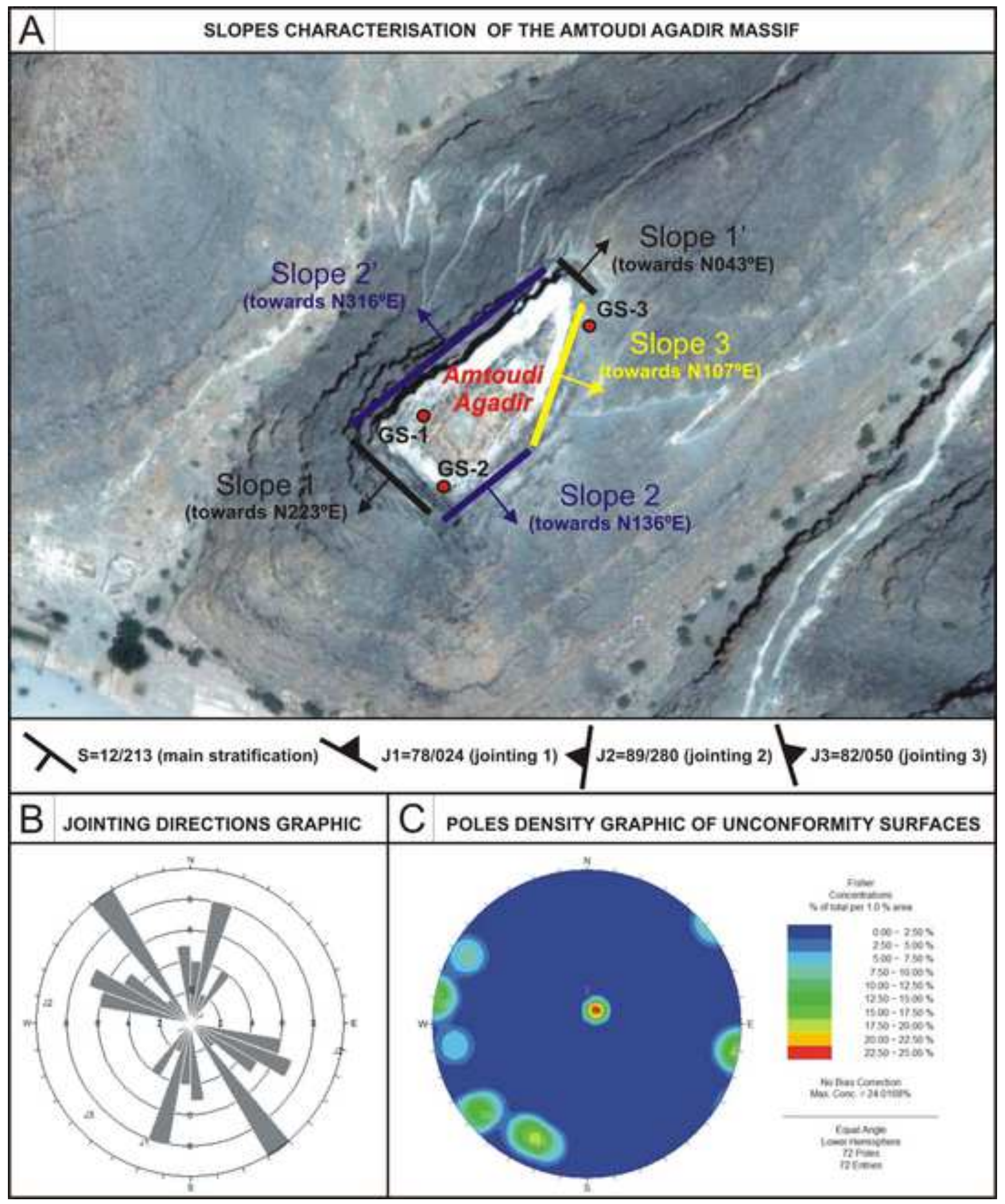




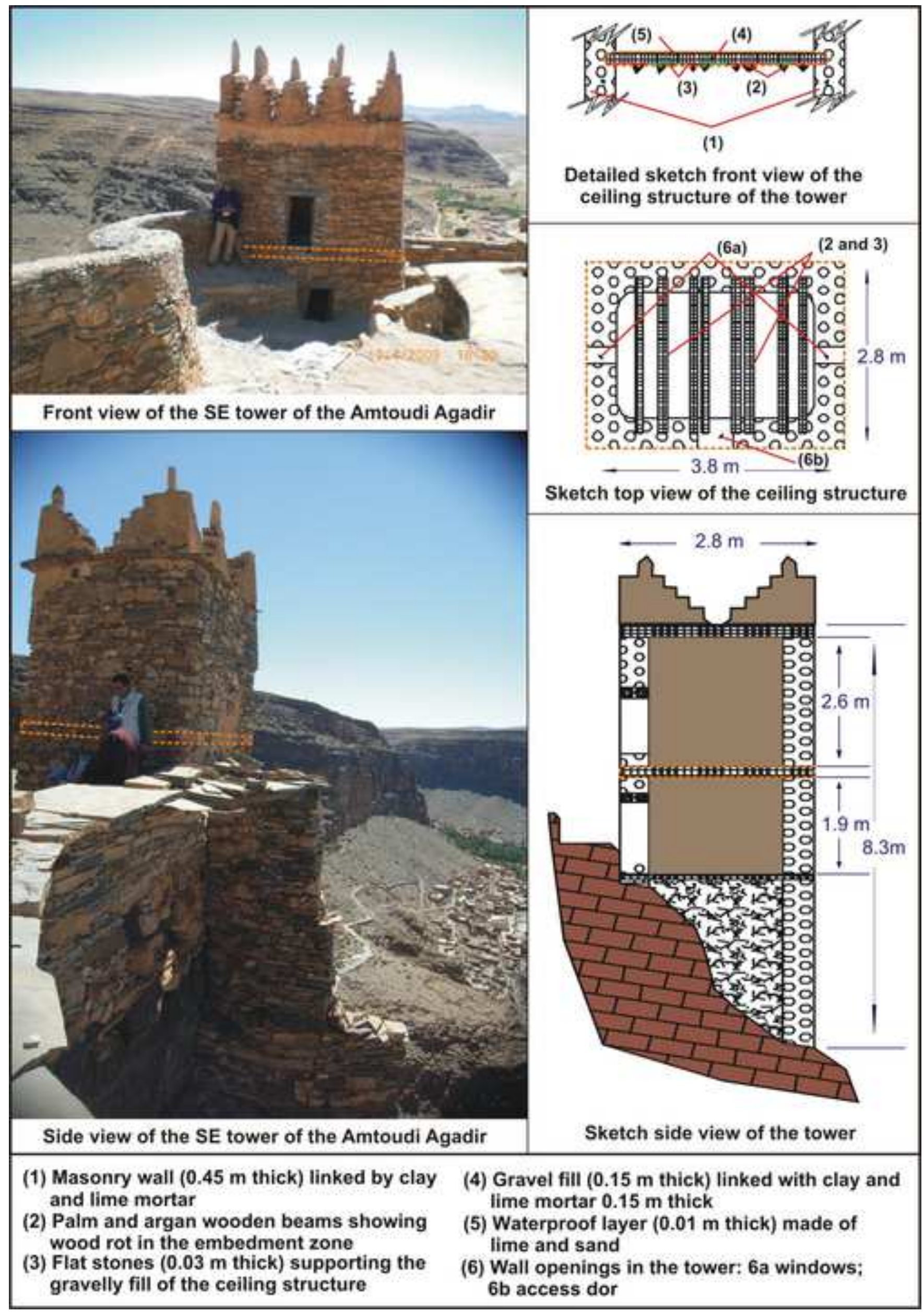


Click here to download high resolution image
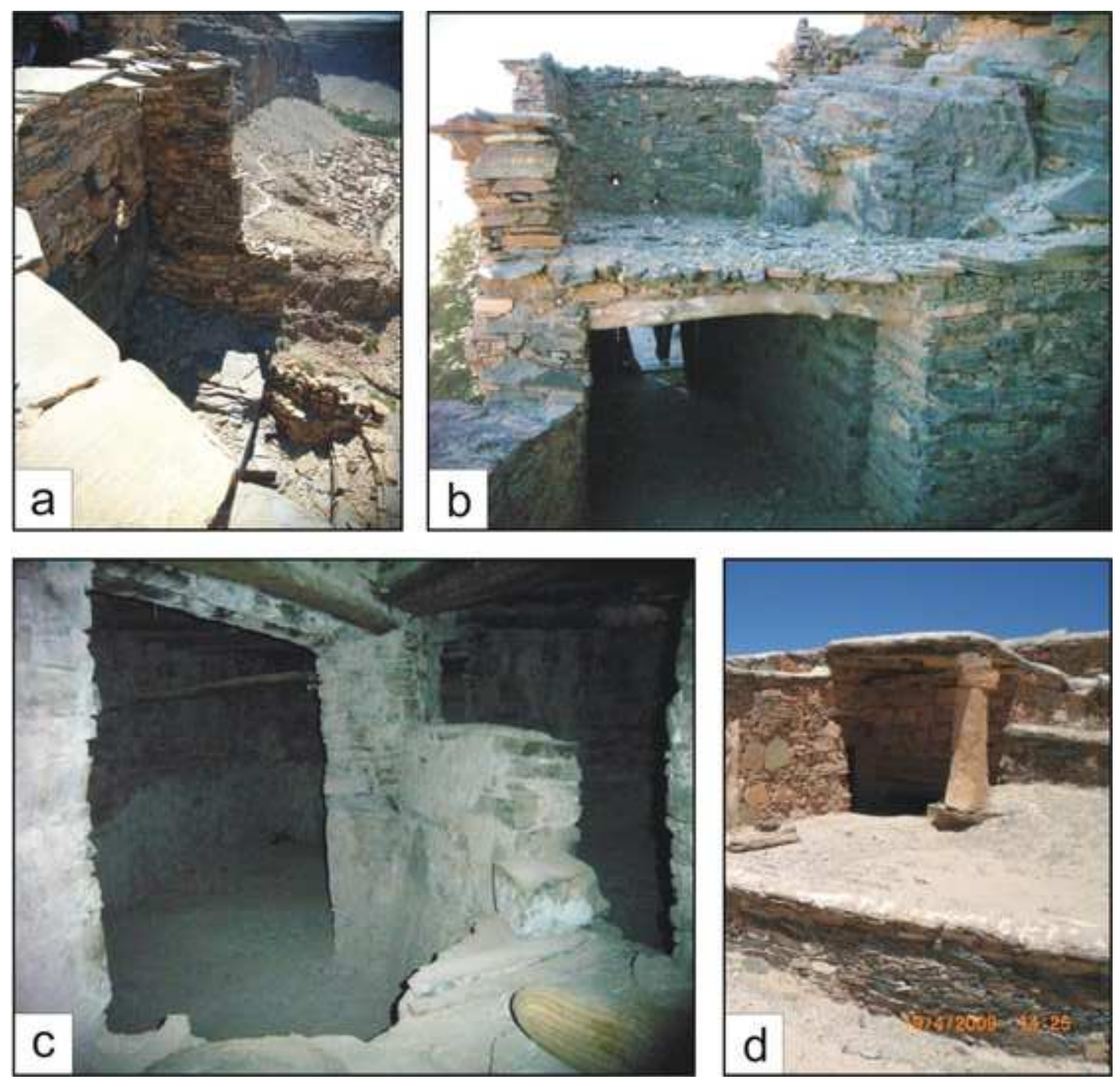
Click here to download high resolution image
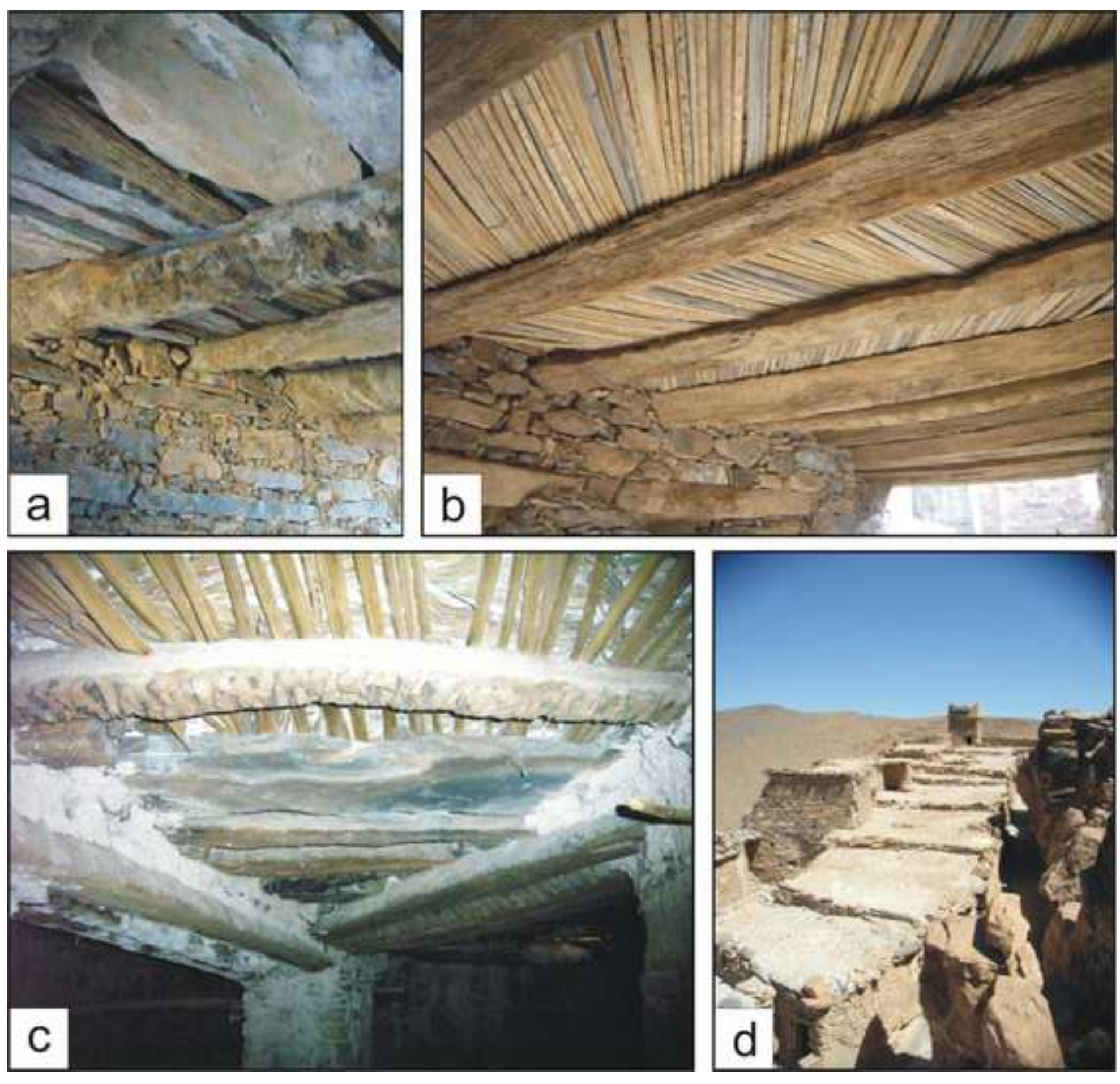


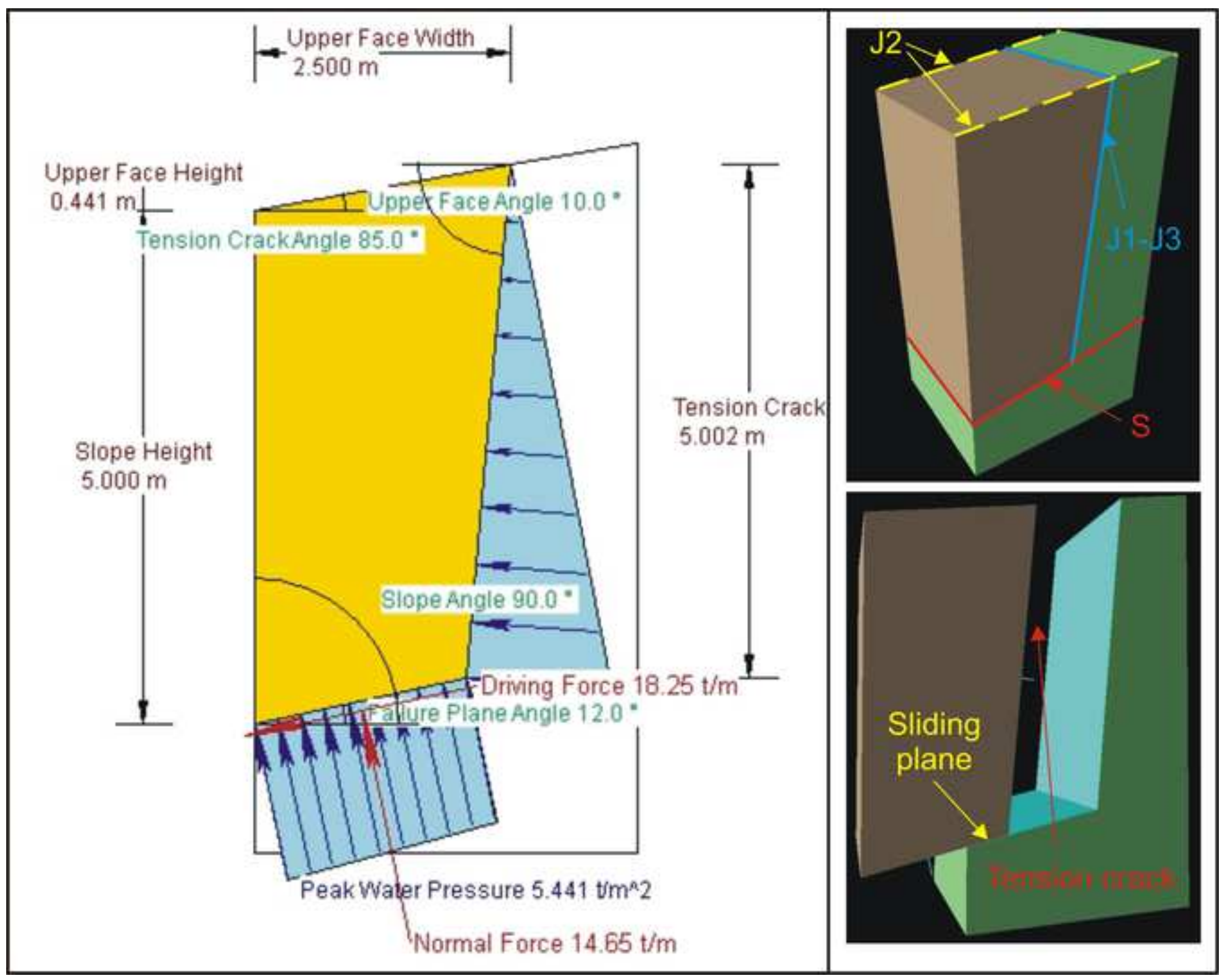


Click here to download high resolution image
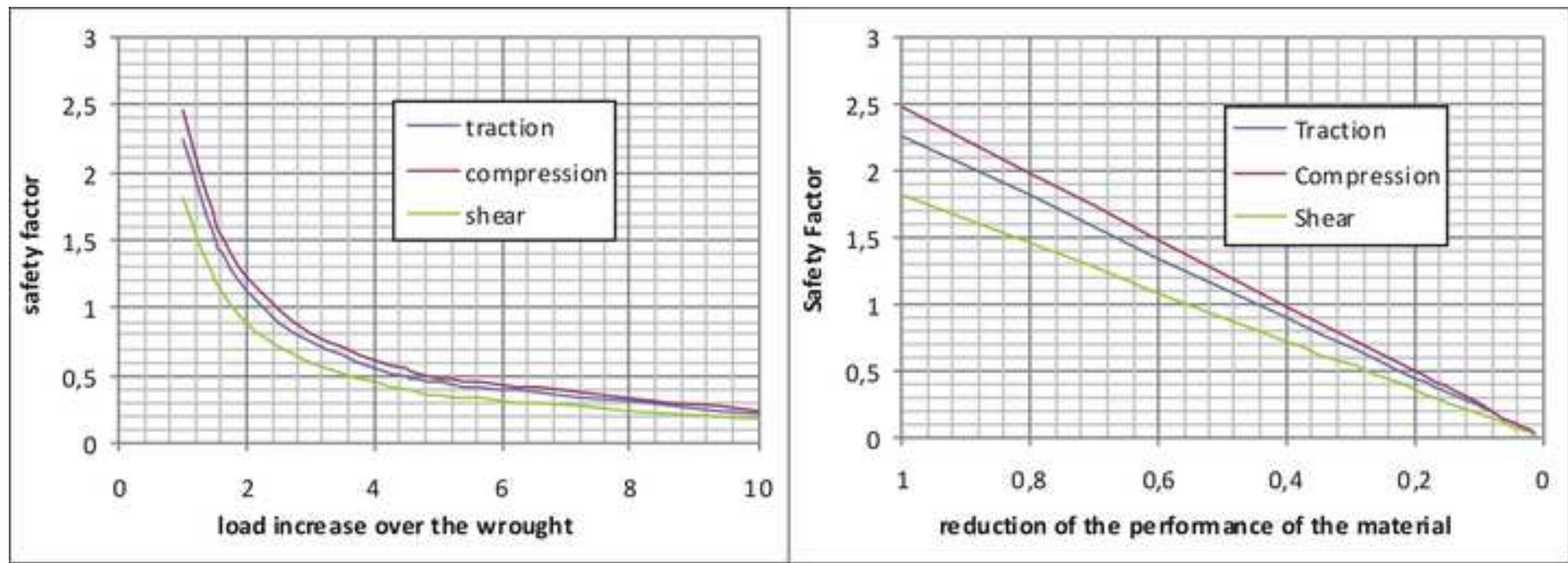
Figure 11

Click here to download high resolution image
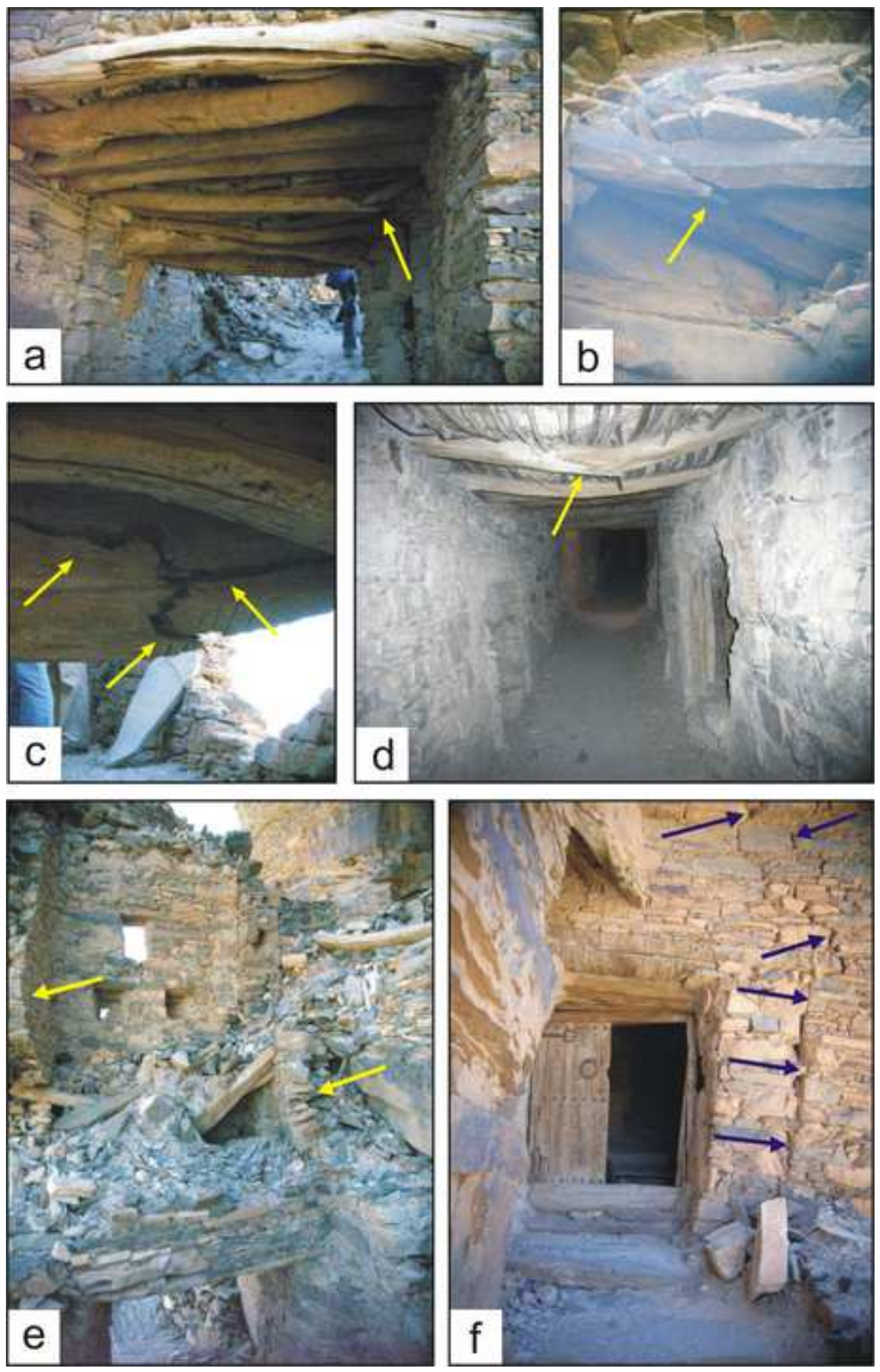
Click here to download Table: renamed_5dba9.doc

\begin{tabular}{|l|l|l|}
\hline Expression $^{(a)}$ & $\mathrm{T}(\mathrm{h})$ & Reference \\
\hline$T=0.3\left(\frac{L}{S^{0.25}}\right)^{0.76}$ & 12.1 & Témez (1978) \\
\hline$T=0.066\left(\frac{L}{S^{0.5}}\right)^{0.77}$ & 6.4 & US Bureau of Reclamation (1973) \\
\hline$T=\frac{4 A^{0.5}+1.5 L}{0.8\left(H_{M}-H_{O}\right)^{0.5}}$ & 13.1 & Giandotti (1934) \\
\hline$T=0.274\left(\frac{L}{S^{0.5}}\right)^{0.64}$ & 12.3 & Chow et al. (1988) \\
\hline (a)
\end{tabular}
[http://srtm.csi.cgiar.org/].

Table 1 


\begin{tabular}{|c|c|c|}
\hline Field lithology & Micro-photograph & Thin section description \\
\hline & & $\begin{array}{l}\text { Claystone/Siltstone (Intervals B and } \\
\text { D; samples 3A, 3B, and 3C) } \\
\text { Claystone: characterized by clayey } \\
\text { matrix and a coarse fraction with } \\
\text { muscovite and coarse and oriented } \\
\text { chlorite. } \\
\text { Siltstone: shows a clayey matrix very } \\
\text { rich in fine grains of quartz. Few } \\
\text { opaque minerals (Fe-oxides and } \\
\text { pyrite) are also present. }\end{array}$ \\
\hline & & $\begin{array}{l}\text { Schist } \\
\text { (Interval D; sample 6) } \\
\text { Characterized by a matrix rich in } \\
\text { small grains of quartz and some } \\
\text { plagioclase. The coarse fraction is } \\
\text { composed mainly of chlorite more or } \\
\text { less twisted and oriented parallel to } \\
\text { the schistosity planes. Some opaque } \\
\text { minerals (Fe-oxides and pyrite) have } \\
\text { been also detected. }\end{array}$ \\
\hline & & $\begin{array}{l}\text { Arkosic sandstones } \\
\text { (Intervals C and D; samples 2, } 5 \text { and } \\
\text { 9B) } \\
\text { Show mainly angular grains of quartz } \\
\text { and minor plagioclases. In some } \\
\text { samples mica flakes have been } \\
\text { detected and significant amounts of } \\
\text { opaque minerals. Carbonatic cement } \\
\text { is found in all cases. }\end{array}$ \\
\hline & & $\begin{array}{c}\text { Wackestone/Grainstone } \\
\text { (Intervals A, B and D; } \\
\text { samples 1, 2, 4, 8, 9A, 11 and 12) } \\
\text { Show a sharp petrographic variation } \\
\text { from brownish fine-grained } \\
\text { carbonates levels (often comprise } \\
\text { angular grains of quartz and very rare } \\
\text { mica flakes) to gray levels rich in } \\
\text { grains of quartz and feldspars and } \\
\text { traces of carbonates. }\end{array}$ \\
\hline
\end{tabular}

Table 2 


\begin{tabular}{|c|c|c|c|c|}
\hline \multicolumn{5}{|c|}{ UNCONFORMITY CHARACTERISTICS } \\
\hline Lithology & Green grainstones (stratigraphic interval C) \\
\hline Unconformity & $\mathrm{S}$ & $\mathrm{J} 1$ & $\mathrm{~J} 2$ & $\mathrm{~J} 3$ \\
\hline Dipping & $12 / 213$ & $78 / 024$ & $89 / 280$ & $82 / 050$ \\
\hline Rebound index & 39 & 36 & 60 & 44 \\
\hline Continuity (m) & $>20$ & $>10$ & $>10$ & $>10$ \\
\hline Mean spacing (m) & 1,05 & 1,22 & 0,87 & 1,01 \\
\hline Aperture (mm) & $<0,1$ & 11 & 12 & 29 \\
\hline $\begin{array}{c}\text { Roughness } \\
\text { (JRC) }\end{array}$ & Soft 3 & Wavy 6 & Soft 2 & Wavy 7 \\
\hline Filling & --- & Hard & Hard & Hard \\
\hline Weathering (a) & 0,91 & 0,74 & 0,71 & 0,88 \\
\hline Wetting & Dry & Dry & Dry & Dry \\
\hline (a) all are slightly
\end{tabular}

Table 3 


\begin{tabular}{|c|c|c|c|c|}
\hline \multicolumn{5}{|c|}{ CLASSIFICATIONS ACCORDING TO SLOPES } \\
\hline \multirow{2}{*}{ Slope } & Classification & Score & Quality rating & More affecting jointing system \\
\hline \multirow{2}{*}{1} & RMR & 11 & Class V & $\mathrm{J} 1$ and J3 \\
\cline { 2 - 5 } & SMR & 76 & Class Ila & $\mathrm{J} 1$ \\
\hline \multirow{2}{*}{1} & RMR & 20 & Class V & $\mathrm{J} 2$ \\
\cline { 2 - 5 } & SMR & 45 & Class Illb & $\mathrm{J} 3$ \\
\hline \multirow{2}{*}{2} & RMR & 20 & Class V & $\mathrm{J} 2$ \\
\cline { 2 - 5 } & SMR & 79 & Class Ila & $\mathrm{J} 3$ \\
\cline { 2 - 5 } 2 & RMR & 21 & Class IV & $\mathrm{J} 3$ \\
\hline \multirow{2}{*}{3} & SMR & 77 & Class Ila & $\mathrm{J} 1$ \\
\cline { 2 - 5 } & RMR & 10 & Class V & $\mathrm{J} 2$ \\
\hline
\end{tabular}

(a) Classes Ila and Ilb: stable; Class IIlb: partially stable; Class IV: bad quality; Class V: very bad quality

Table 4 


\begin{tabular}{|c|c|c|c|c|}
\hline \multirow{2}{*}{$\begin{array}{c}\text { Block } \\
\text { height } \\
(\mathbf{m})\end{array}$} & \multicolumn{4}{|c|}{$\begin{array}{c}\text { PLANAR SLIDING SAFETY FACTORS } \\
(<1 \text { means instability })\end{array}$} \\
\cline { 2 - 5 } & $\begin{array}{c}\text { Only under } \\
\text { gravitational } \\
\text { conditions }\end{array}$ & $\begin{array}{c}\text { Gravitational and } \\
\text { seismic } \\
\text { conditions }\end{array}$ & $\begin{array}{c}\text { Gravitational and water-saturation } \\
\text { conditions }\end{array}$ \\
\cline { 4 - 5 } & 3.76 & 2.90 & Drained & Not drained \\
\hline 5 & 3.72 & 2.86 & 1.62 & 0.66 \\
\hline 10 & & 1.60 & 0.64 \\
\hline
\end{tabular}

Table 5 


\begin{tabular}{|c|l|l|}
\hline & \multicolumn{1}{|c|}{ STRUCTURAL WALLS } & \multicolumn{1}{c|}{ CEILING STRUCTURES } \\
\hline $\begin{array}{c}\text { CONSTRUCTION } \\
\text { PROBLEMS }\end{array}$ & $\begin{array}{l}\text { - instability for the lack of verticality of } \\
\text { walls } \\
\text { - instability for excessive thinning } \\
\text { - cracking for the lack of interlocking } \\
\text { joints in the masonry sometimes due to } \\
\text { disparate stone sizes or lack of mortar }\end{array}$ & $\begin{array}{l}\text { - failure by flexure due to overload } \\
\text { over the beams } \\
\text { - lack of homogeneity in the load } \\
\text { distribution for irregular geometry } \\
\text { (curve) of the joists } \\
\text { - failure by lack of support }\end{array}$ \\
\hline $\begin{array}{c}\text { MAINTENANCE } \\
\text { PROBLEMS }\end{array}$ & $\begin{array}{l}\text { - disaggregation by washing out of the } \\
\text { mortar }\end{array}$ & $\begin{array}{l}\text { - Fatigue resistance of the beams } \\
\text { - instability by mobilizing pore } \\
\text { - failure by shearing of the wooden } \\
\text { pressures }\end{array}$ \\
\hline
\end{tabular}

Table 6 